\title{
Pathogens, parasites, and parasitoids associated with bumble bees (Bombus spp.) from Uruguay
}

\author{
Santiago Plischur ${ }^{1}$, Sheena Salvarrey ${ }^{2}$, Natalia Arbulo ${ }^{3}$, Estela Santos ${ }^{2}$, \\ Jeffrey H. Skevington ${ }^{4}$, Scott Kelso ${ }^{4}$, Pablo D. Revainera ${ }^{5}$, Matías D. MagGi ${ }^{5}$, \\ Ciro InvernizzI ${ }^{2}$, Carlos E. Lange ${ }^{1,6}$ \\ ${ }^{1}$ Centro de Estudios Parasitológicos y de Vectores (CCT La Plata CONICET-UNLP), Boulevard 120 \# 1460, 1900, La \\ Plata, Argentina \\ ${ }^{2}$ Facultad de Ciencias, Universidad de la República, Montevideo, Uruguay \\ ${ }^{3}$ Centro Universitario Regional del Este, Universidad de la República, Rocha, Uruguay \\ ${ }^{4}$ Canadian National Collection of Insects, Arachnids and Nematodes, Agriculture and Agri-Food Canada, Ottawa, \\ Canada \\ ${ }^{5}$ Centro de Investigación en Abejas Sociales (UNMdP), CONICET, Mar del Plata, Argentina \\ ${ }^{6}$ Comisión de Investigaciones Científicas de la Provincia de Buenos Aires (CICPBA), La Plata, Argentina
}

Received 6 July 2016 - Revised 24 August 2016 - Accepted 21 September 2016

\begin{abstract}
As elsewhere in the world, bumble bees play a vital role as pollinators in Uruguay, but knowledge on their health status is still limited. Between September 2012 and May 2013, 403 adult individuals of the two species of Bombus known for the country (Bombus atratus, Bombus bellicosus ) were collected in six localities. We found that $177(119 \mathrm{~B}$. atratus , $58 \mathrm{~B}$. bellicosus $)$ were harboring one or two types of pathogens, parasites, or parasitoids. Identification of these natural enemies carried out by morphological or molecular procedures revealed the presence of two species of Microsporidia [Nosema ceranae (prevalence: $18.2 \%$ in B. atratus; $44.9 \%$ in B. bellicosus), Tubulinosema pampeana (prevalence: $13 \%$ in B. atratus)], two species of Nematoda [Sphaerularia bombi (prevalence: $40.4 \%$ in $B$. atratus ; $40 \%$ in B. bellicosus) and an unidentified Mermithidae (prevalence: $0.8 \%$ in B. bellicosus)], and one species of Diptera parasitoid (prevalence: $3.2 \%$ in B. atratus; $4.2 \%$ in B. bellicosus). Except $N$. ceranae, none of the other species have been previously reported in Uruguay.
\end{abstract}

\section{Conopidae / Microsporidia / Nematoda / pollinator}

\section{INTRODUCTION}

Of the 250 species of Bombus bumble bees currently recognized worldwide (Cameron et al. 2007), two are known to occur in Uruguay,

Electronic supplementary material The online version of this article (doi:10.1007/s13592-016-0474-2) contains supplementary material, which is available to authorized users.

Corresponding author: S. Plischuk, santiago@cepave.edu.ar Manuscript Editor: James Nieh
Bombus atratus Franklin ${ }^{1}$ and B. bellicosus Smith (Santos et al. 2013). Both are relatively common in southern South America and abundant in the Pampas region. Since much of this region has become a heavily used agro-ecosystem, these insects provide essential pollination services not only for relict natural vegetation but also for a variety of crops (Arbulo et al. 2011). Despite their central relevance in such an important process and

\footnotetext{
${ }^{1}$ The widely adopted name $B$. atratus is used in this contribution although according to some authors (Moure and Melo 2012), the valid one would be Bombus pauloensis.
} 
although pathogens and parasites have been signaled as a relevant mortality factor (Kissinger et al. 2011 and references therein), the current health status of bumble bees in Uruguay is still poorly known being the microsporidium Nosema ceranae Fries et al. the only pathogen reported in the country associated with these insects (Arbulo et al. 2015). With the aim to increase the knowledge about the diversity of pathogens, parasites, and parasitoids naturally harbored by Bombus species known to inhabit this area, we provide novel information on the presence, prevalence, intensity of infections, and co-infection rates of the parasitic natural enemy complex ${ }^{2}$ associated to $B$. atratus and B. bellicosus .

\section{MATERIALS AND METHODS}

A total of 403 adult bumble bees (285 B. atratus, 118 B. bellicosus) were individually collected at six localities belonging to five departments ${ }^{3}$ in southern Uruguay [INIA-La Estanzuela (Dept. Colonia), Montevideo (Dept. Montevideo), Sarandí Grande (Dept. Florida), Villa Soriano (Dept. Soriano), Sauce (Dept. Canelones), Canelón Chico (Dept. Canelones); Table I, Figure 1] between September 2012 and April 2013. They were captured while foraging using plastic jars directly from flowers and conserved until dissection either in $70 \%$ ethanol or frozen $\left(-32{ }^{\circ} \mathrm{C}\right)$. Individuals were dissected using a Nikon SMZ745T stereoscopic microscope $(\times 10, \times 40)$ (Lange 1996). Initially, bumble bees were checked for parasites and parasitoids of the metasomal cavity such as nematodes and juvenile dipteran stages. Afterwards, tracheae were scrutinized for mites. Finally, small portions of different tissues and organs were extracted in order to prepare fresh smears with one-quarter-strength Ringer's solution (Poinar and Thomas 1984) for detection of microsporidia and protists (Lange and Lord 2012; Solter et al. 2012). Observations were done using phase-contrast microscopy (Nikon E200; $\times 400, \times 1000$ ). Microsporidia spore suspensions were obtained by homogenization of the whole infected insect in $2 \mathrm{~mL}$ of distilled water and

\footnotetext{
$\overline{2}$ Into "parasitic natural enemy complex" we include pathogens, parasites, and parasitoids as defined by Onstad et al. (2006).

${ }^{3}$ Main national geographic subdivisions.
}

quantified using an Improved Neubauer hemocytometer by counting of spores (Undeen and Vávra 1997).

Due to morphological similarity between species of Nosema , the microsporidia genus known to be associated with bumble bees, molecular identification was carried out by Multiplex PCR using specific primers for 16S SSU rRNA of Nosema ceranae (218MITOC), Nosema apis Zander (321APIS), and Nosema bombi Fantham and Porter (BOMBICAR) (see Plischuk et al. 2009). Briefly, genetic material was extracted from infected tissues before homogenization using a QIAamp Viral RNA Mini Kit (Qiagen) following the manufacturer's instructions but modifying the final volume of $60 \mu \mathrm{L}$ of elution with AVE buffer to a final volume of $46 \mu \mathrm{L}$. Multiplex reactions were performed in a volume of $25 \mu \mathrm{L}$ using $1.5 \mu \mathrm{L}$ of $\mathrm{MgCl}_{2}(50 \mathrm{mM}), 2.5 \mu \mathrm{L}$ of PCR $10 \times$ buffer, $0.2 \mu \mathrm{L}$ of Taq polymerase $(50 \mathrm{U} / \mu \mathrm{L})$, $1 \mu \mathrm{L}$ of dNTPs $(10 \mathrm{mM}), 0.25$ of each primer $(40 \mu \mathrm{M})$, and $2.5 \mu \mathrm{L}$ of template DNA. Final volume was achieved with distilled water. Samples were denatured at $94{ }^{\circ} \mathrm{C}$ for $2 \mathrm{~min}$ followed by 10 cycles of $94{ }^{\circ} \mathrm{C}$ for $15 \mathrm{~s}, 61.8^{\circ} \mathrm{C}$ for $30 \mathrm{~s}$, and $72{ }^{\circ} \mathrm{C}$ for $45 \mathrm{~s}$. After that, 20 cycles were added but increasing $5 \mathrm{~s}$ to the last step of each one, followed by a final extension step of $72{ }^{\circ} \mathrm{C}$ for $7 \mathrm{~min}$. Positive controls were provided by Dr. Mariano Higes, Centro Agrario de Marchamalo, Spain. Amplification products were analyzed by $2 \%$ agarose gels in TBE $0.5 \times$ buffer (Tris $10.8 \mathrm{~g}$, boric acid $5.5 \mathrm{~g}$, EDTA $0.5 \mathrm{M} \mathrm{pH} 8,4 \mathrm{~mL}$ per $100 \mathrm{~mL}$ ) and treated with GelRed nucleic acid stain (Biotium, Hayward, USA).

Tubulinosema pampeana Plischuk et al., a recently described microsporidium from $B$. atratus, can be readily identified and differentiated with compound microscopy from Nosema species by its spore size and appearance as well as affected tissue and typical gross pathology (Plischuk et al. 2015).

Observation of Nematoda characters was done using simple stereoscopic microscopy $(\times 10, \times 40)$ as well as compound (bright field) microscopy $(\times 400, \times 1000)$ (Plischuk and Lange 2012). Identification was carried out following appropriate keys (Pouvreau 1962; Poinar 1977; Siddiqi 2000).

Parasitoid larvae hard structures were observed and photographed using both simple $(\times 10, \times 40)$ and compound (bright field) microscopy $(\times 400$, $\times 1000$ ). Soft larval tissues are completely digested when exposed to a Proteinase K-based total DNA extraction protocol. The middle of the larval body was excised for DNA extraction, allowing the 
Table I. Sample localities and prevalence (\%) of pathogens (Microsporidia), parasites (Nematoda), and parasitoids (Diptera) of Bombus atratus and Bombus bellicosus from Uruguay during season 2012-2013 ( $n=403$ )

\begin{tabular}{|c|c|c|c|c|c|c|c|}
\hline \multirow{2}{*}{$\begin{array}{c}\text { Locality } \\
\text { (department) }\end{array}$} & \multirow[t]{2}{*}{ Species } & \multirow{2}{*}{$\begin{array}{l}\text { Caste } \\
(n)\end{array}$} & \multicolumn{2}{|c|}{ Microsporidia } & \multicolumn{2}{|c|}{ Nematoda } & \multirow{2}{*}{$\begin{array}{c}\text { Diptera } \\
\text { Conopidae }\end{array}$} \\
\hline & & & $\begin{array}{l}\text { Nosema } \\
\text { ceranae }\end{array}$ & $\begin{array}{l}\text { Tubulinosema } \\
\text { pampeana }\end{array}$ & $\begin{array}{c}\text { Sphaerularia } \\
\text { bombi }\end{array}$ & Mermithidae & \\
\hline \multirow{4}{*}{$\begin{array}{l}\text { INIA-La Estanzuela } \\
\text { (Colonia) } 34^{\circ} 20^{\prime} \mathrm{S} \text {; } \\
57^{\circ} 41^{\prime} \mathrm{W}\end{array}$} & B. atratus & W (75) & 45 & - & - & - & 9 \\
\hline & & $\mathrm{M}(2)$ & - & - & - & - & - \\
\hline & B. bellicosus & W (50) & 76 & - & - & 2 & 8 \\
\hline & & M (13) & 15 & - & - & - & - \\
\hline \multirow{2}{*}{$\begin{array}{l}\text { Montevideo } \\
\text { (Montevideo) } 34^{\circ} \\
50^{\prime} \mathrm{S} ; 56^{\circ} 13^{\prime} \mathrm{W}\end{array}$} & B. atratus & Q (93) & 22 & 37 & 41 & - & - \\
\hline & B. bellicosus & Q (5) & - & - & 40 & - & - \\
\hline \multirow{4}{*}{$\begin{array}{l}\text { Sarandí Grande } \\
\text { (Florida) } 33^{\circ} 43^{\prime} \mathrm{S} \text {; } \\
56^{\circ} 20^{\prime} \mathrm{W}\end{array}$} & B. atratus & W (27) & 22 & - & - & - & 8 \\
\hline & & M (19) & 11 & - & - & - & 5 \\
\hline & B. bellicosus & $\mathrm{W}(22)$ & 45 & - & - & - & 5 \\
\hline & & M (10) & - & - & - & - & - \\
\hline \multirow{2}{*}{$\begin{array}{r}\text { Villa Soriano (Soriano) } \\
33^{\circ} 24^{\prime} \mathrm{S} ; 58^{\circ} 19^{\prime} \mathrm{W}\end{array}$} & B. atratus & W (15) & 7 & - & - & - & - \\
\hline & B. bellicosus & W (2) & - & - & - & - & - \\
\hline \multirow{5}{*}{$\begin{array}{l}\text { Sauce (Canelones) } \\
34^{\circ} 40^{\prime} \mathrm{S} ; 56^{\circ} 02^{\prime} \mathrm{W}\end{array}$} & B. atratus & Q (1) & - & - & - & - & - \\
\hline & & $\mathrm{W}(40)$ & 18 & 2 & - & - & - \\
\hline & & M (2) & - & - & - & - & - \\
\hline & B. bellicosus & W (15) & 7 & - & - & - & - \\
\hline & & M (1) & - & - & - & - & - \\
\hline $\begin{array}{l}\text { Canelón Chico } \\
\text { (Canelones) } 34^{\circ} 39^{\prime} \\
\mathrm{S} ; 56^{\circ} 11^{\prime} \mathrm{W}\end{array}$ & B. atratus & W (11) & - & 18 & - & - & - \\
\hline
\end{tabular}

$W$ workers, $M$ males, $Q$ queens

cephalopharyngeal skeleton and posterior spiracles to be retained as vouchers for each of the specimens studied. Total DNA was extracted using a DNeasy® Tissue kit (Qiagen Inc., Santa Clara, CA, USA) following the manufacturer's protocol. DNA amplifications were carried out in $25-\mu \mathrm{L}$ reactions with $15.7 \mu \mathrm{L} \mathrm{ddH} \mathrm{d}_{2} \mathrm{O}, 2.5 \mu \mathrm{L} 10 \times$ PCR buffer, $0.65 \mu \mathrm{L}$ $25 \mathrm{mM} \mathrm{MgCl}_{2}, 1.0 \mu \mathrm{L}$ of each $10 \mu \mathrm{M}$ primer, $2.0 \mu \mathrm{L}$ $10 \mathrm{mM}$ dNTPs, $0.15 \mu \mathrm{L}$ ExTaq Hot Start DNA polymerase (Takara Bio Inc., Otsu, Shiga, Japan), and $2 \mu \mathrm{L}$ genomic DNA template. A 658-base-pair fragment of the $5^{\prime}$ end of the COI gene was amplified using the primer pair LCO1490 (5'-GGTC AACAAATCATAAAGATATTGG-3') (Folmer et al. $1994)$ and COI-DIPT-2183R (5'-CCAA AAAATCARAATARRTGYTG-3') (Gibson et al. 2011). Positive PCR products were purified with ExoSap-IT reagent (USB Corp., Cleveland, OH) following manufacturer's recommendations prior to sequencing. Sequencing reactions were carried out using an ABI BigDye Terminator v3.1 Cycle Sequencing kit (PE Applied Biosystems, Foster City, $\mathrm{CA}$ ) in a volume of $10 \mu \mathrm{L}$ containing $5 \mu \mathrm{L}$ purified PCR template, $1.5 \mu \mathrm{L} 5 \times$ sequencing buffer, $2 \mu \mathrm{L}$ $\mathrm{ddH} 2 \mathrm{O}, 0.5 \mu \mathrm{L} 10 \mu \mathrm{M}$ primer, and $1 \mu \mathrm{L}$ ABI Big Dye reagent and were purified using the ABI ethanol/EDTA/ sodium acetate precipitation protocol. They were analyzed on an ABI 3130xl Genetic Analyzer (PE Applied Biosystems) and identified by comparison to known sequences in GenBank using BLAST.

\section{RESULTS}

Two species of Microsporidia, one Nematode species, and one Diptera species were found in 


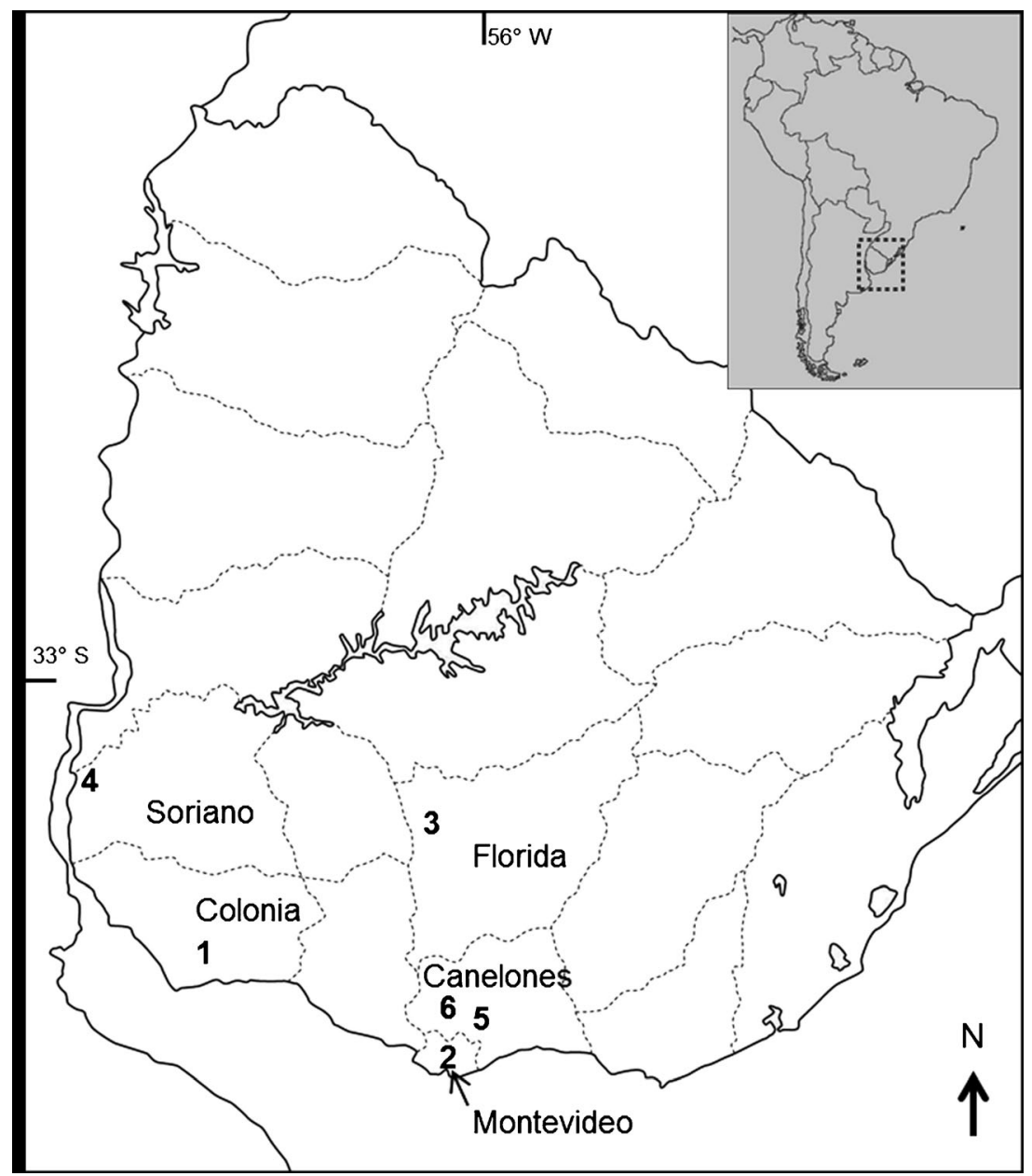

Figure 1 Sampling sites of Bombus atratus and Bombus bellicosus in Uruguay during season 2012-2013. 1 INIALa Estanzuela, 2 Montevideo, 3 Sarandí Grande, 4 Villa Soriano, 5 Sauce, 6 Canelón Chico. Name of each department is indicated on the map

B. atratus, whereas one Microsporidium, two Nematodes, and one Diptera species were detected in association with $B$. bellicosus (Table I). Out of the 403 bumble bees sampled, 177 (119 B. atratus, 58 B. bellicosus ) harbored either one or two types of natural enemies (pathogen, parasite, or parasitoid; Figure 2).

\subsection{Pathogens}

The microsporidium $N$. ceranae was found in both Bombus species (Table I; Figure 3a). Prevalence was $18.2 \%$ in B. atratus and $44.9 \%$ in $B$. bellicosus. Workers were the most infected caste in both species [28.6\% in B. atratus
( $n=168$ workers); $55.1 \%$ in $B$. bellicosus ( $n=89$ workers)]. Prevalence in males was $8.7 \%$ in B. atratus ( $n=23$ males) and $16.7 \%$ in B. bellicosus $(n=24)$, while in queens was $2.1 \%$ in B. atratus ( $n=94$ queens). Infections in queens of $B$. bellicosus $(n=5)$ were not detected. Infected bees were collected in five of the six sampling localities (Table I), and $5.7 \%$ showed some co-infection (Figure 2). Mean spore loads per bumble bee in workers were $1.2 \times 10^{7}$ in $B$. atratus and $2.0 \times 10^{7}$ in B. bellicosus. Males of $B$. atratus showed an average spore load of $3.3 \times 10^{5}$, while mean load of $B$. bellicosus males was $4.0 \times 10^{5}$. Finally, mean spore load of $B$. atratus queens was $6.5 \times 10^{6}$. 


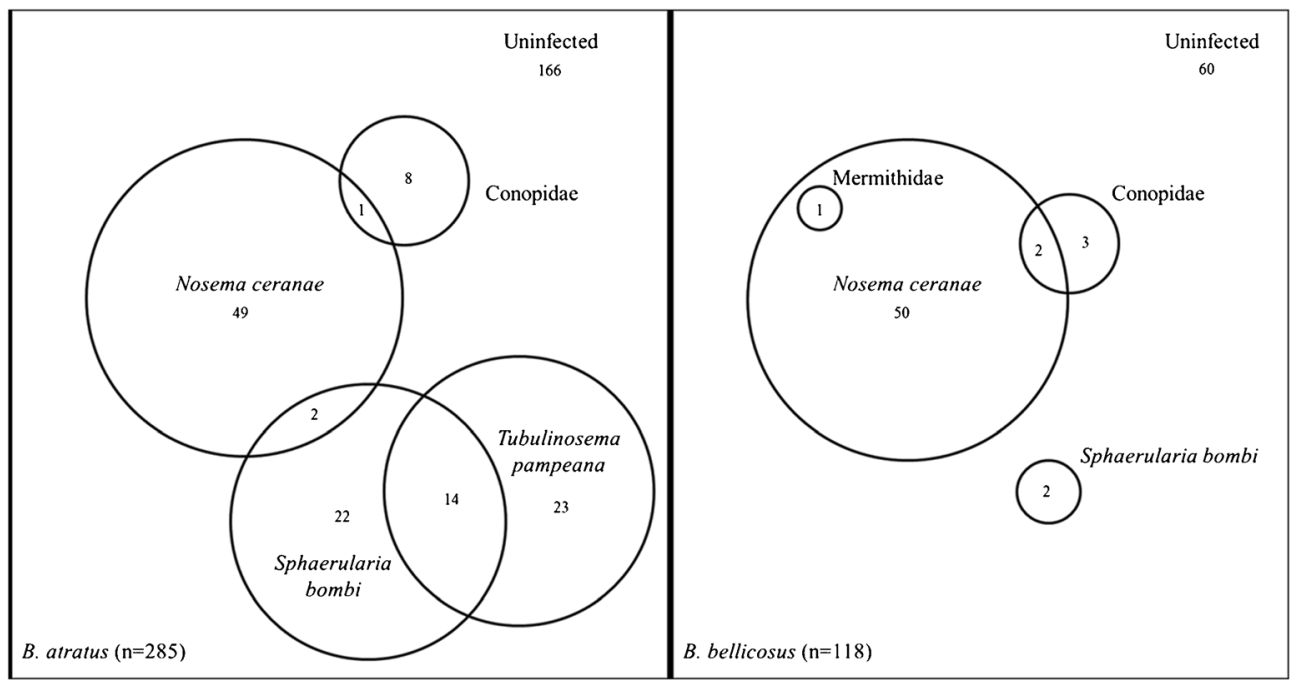

Figure 2 Host sharing of pathogens (Microsporidia), parasites (Nematoda), and parasitoids (Diptera) in Bombus atratus and Bombus bellicosus from Uruguay during season 2012-2013. Areas of circles are proportional to numbers inside [ $n=403$; design adapted from Rutrecht and Brown (2008)]

The other microsporidium, T. pampeana (Figure 3b), was detected only in association with B. atratus in a prevalence of $13 \%$. Queens were the most infected caste $(36.2 \% ; n=94)$, followed by workers $(1.8 \% ; n=168)$. Infections were not detected in any of the 23 sampled males. Tubulinosema pampeana was present in the three southernmost localities (Table I). More than $37 \%$ of Tubulinosema -positive bees were also parasitized by the nematode Sphaerularia bombi Dufour (see below) (Figure 2). Averaged spore loads were $2.2 \times 10^{8}$ in queens and $8.1 \times 10^{7}$ in workers.

\subsection{Parasites}

Two kinds of nematodes were found in this survey. Sphaerularia bombi (Tylenchida: Sphaerulariidae) was isolated from both Bombus species (Figure 4a, b). In B. atratus, a prevalence of $40.4 \%$ and a mean intensity of four adult
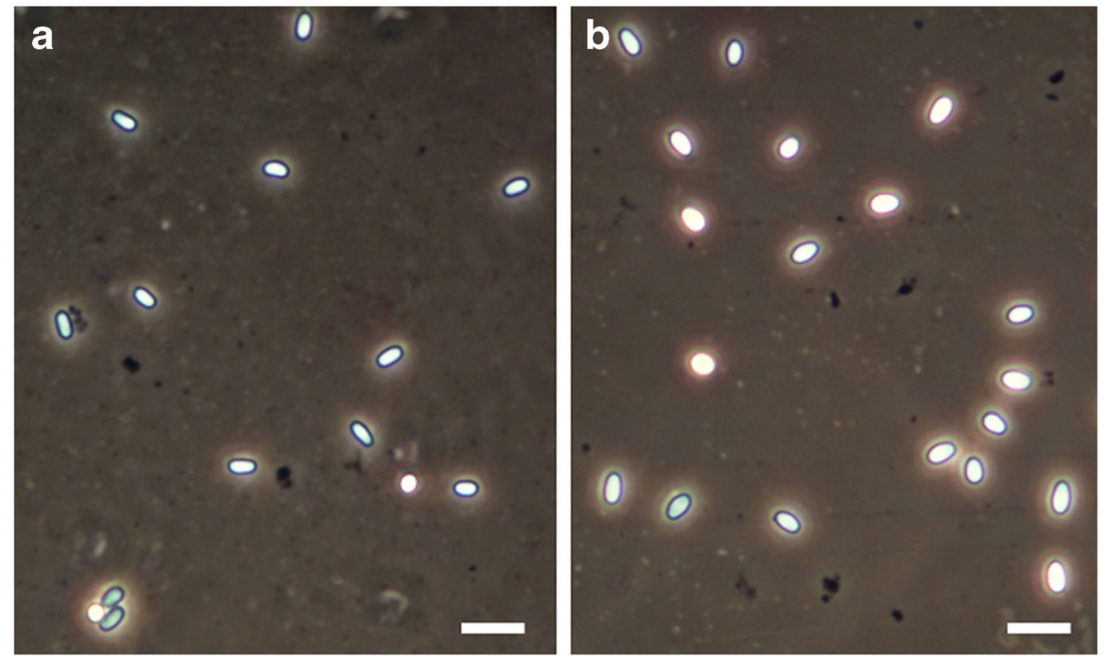

Figure 3 Spores of pathogens (Microsporidia) found in Bombus atratus and Bombus bellicosus from Uruguay during season 2012-2013. a Nosema ceranae, b Tubulinosema pampeana . [Phase contrast; bars $=10 \mu \mathrm{m}$ ] 
females per queen (range $1-24 ; n=38$ ) was registered. Sixteen Sphaerularia-positive bees $(42.1 \%)$ also harbored one of the two detected microsporidia, $N$. ceranae or $T$. pampeana (Figure 2). Regarding B. bellicosus, two parasitized individuals were found out of the five queens collected. Intensity was one adult female per queen in both specimens; co-infections with microsporidia were not registered. Sphaerularia bombi was detected only in Montevideo.

One $N$. ceranae -infected worker of B. bellicosus from INIA-La Estanzuela (Dept. Colonia) was found parasitized by a different kind of nematode. Two worms matching the description of late parasitic/postparasitic mermithid (Mermithidae) juveniles (Poinar 1977; Stock and Goodrich Blair 2012) were isolated from the bee metasomal hemocoel. Both larvae were relatively thin (mean length $1.00 \mathrm{~mm}$, mean width at mid-body $0.35 \mathrm{~mm}$ ), with the anterior margin of head rounded. The mouth was apical, central, and terminal. Tail appendage was present and averaged $52 \mu \mathrm{m}$ in length (Figure $4 \mathrm{c}, \mathrm{d}$ ).

\subsection{Parasitoids}

Dipteran larvae were found in both $B$. atratus and $B$. bellicosus, and prevalence ranged between 1 and $8 \%$. Larvae were isolated from workers and males, but not from queens, and no more than one larva per bumble bee was found. Larvae were pyriform, white to dark brown. All had a pair of posterior, more or less developed spiracles, and an anterior, sclerosed cephalopharyngeal skeleton. After observation of larval measurements, cephalopharyngeal skeleton architecture and spiracles, as well as the interaction of larvae with the host's tracheal system, three stages could be individualized (Schmid-Hempel and Schmid-Hempel 1996; Abdalla et al. 2014): (1) one specimen at L1/L2 stage (2.48 $\mathrm{mm}$ in length) isolated from B. atratus sampled in INIA-La Estanzuela, showed a pair of undeveloped spiracles surrounded by numerous spicules and absence of connection with the host's tracheal trunks. (2) Twelve whitish larvae at L3 stage had spiracular plates with numerous openings elevated on corallike sculpturing and a visible connection between them and the tracheal system of the harboring insect. Larval length averaged 4.89 (2.91-
Figure 4 Nematodes found in Bombus atratus and Bombus bellicosus from Uruguay during season 2012-2013. Sphaerularia bombi: a hypertrophied ovary of an adult female ( $b a r=1 \mathrm{~mm})$, b larva $(L)$ and egg $(E)($ bar $=100 \mu \mathrm{m})$. Mermithidae larva: $\mathbf{c}$ anterior end, d posterior end. [Bright field; bars $=50 \mu \mathrm{m}$ ]

6.50) $\mathrm{mm}$. (Figure 5a, c). (3) One dark, late L3 stage, $8.06 \mathrm{~mm}$ in length, was isolated from B. atratus sampled in Sarandí Grande. This larva showed reddish sclerosed multi-pointed spiracles with wart-like protuberances and absence of connection with the host's tracheal trunks (Figure $5 \mathrm{~b}$ ). Larvae appeared in co-infection with $N$. ceranae at rates of $40 \%$ (in B. bellicosus) and $14.3 \%$ (in $B$. atratus ) (Figure 2). Puparia were not found.

Conopid larvae are also unidentifiable by morphological means at this point in time. Keys for larval identification are not available and few larvae have been described. A modest DNA barcode library has been established by two of the authors (JHS and SK), so identification with molecular methods is feasible. DNA analyses were successful in three samples isolated from B. atratus workers, showing that two of the larvae (from INIA-La Estanzuela and Sarandí Grande) match $99 \%$ with Physocephala nervosa Krober and are very likely this species (accession numbers KX536524 and KX536525, respectively). The third larva (also from INIA-La Estanzuela) is clearly a different species of Physocephala that is not yet in our barcode database. It was also closest to $P$. nervosa but was only $87 \%$ similar (accession number KX536521). Seven specimens failed to yield sequences [see summary on Table II (Online resource)].

\section{DISCUSSION}

\subsection{Pathogens}

Three species of microsporidia are known to be associated with Bombus bumble bees: N. bombi, N. ceranae, and T. pampeana. All of them have been detected previously in South America (Plischuk et al. 2009, 2015; Schmid-Hempel et al. 2014). Although originally described as a 

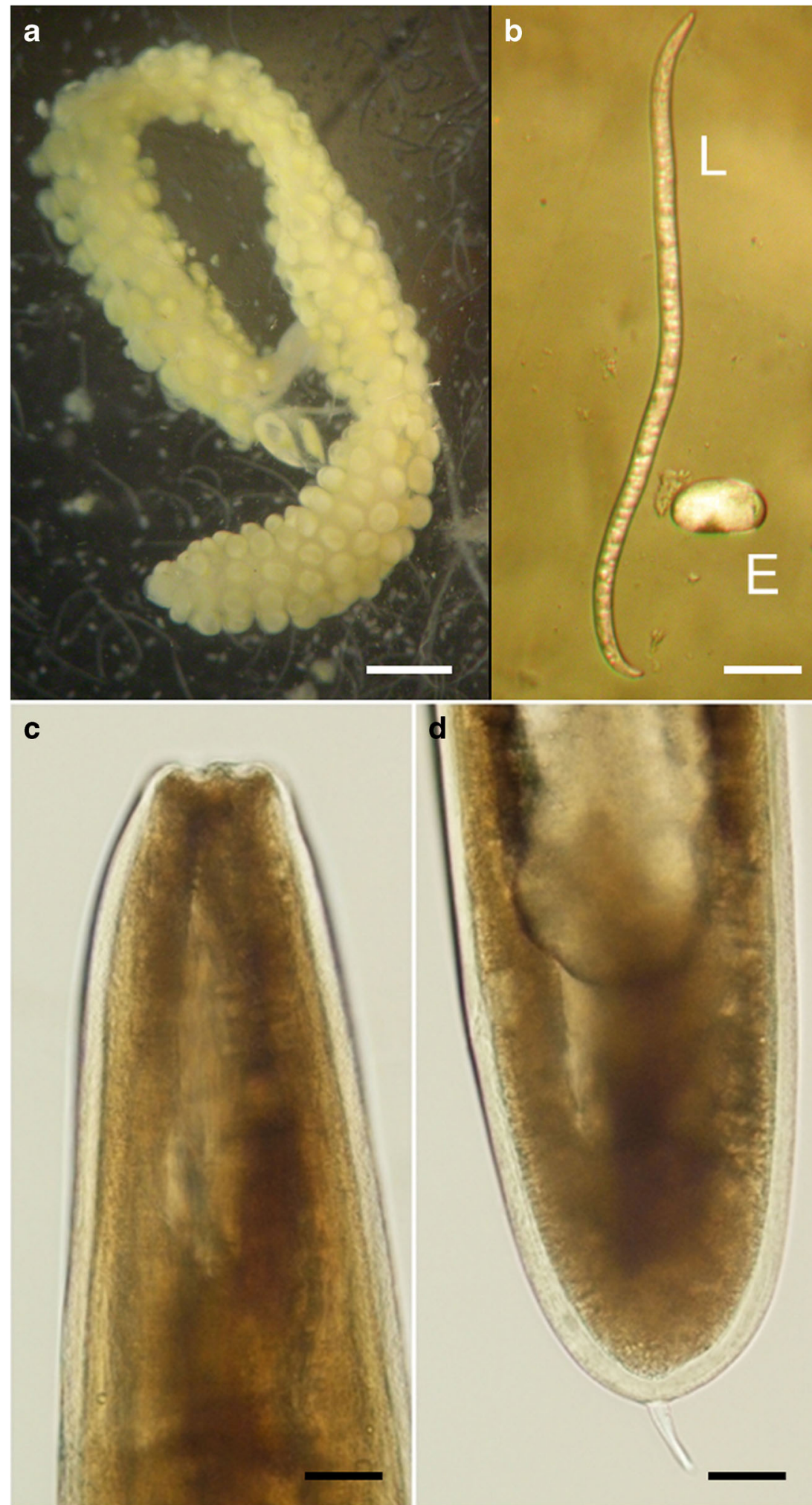

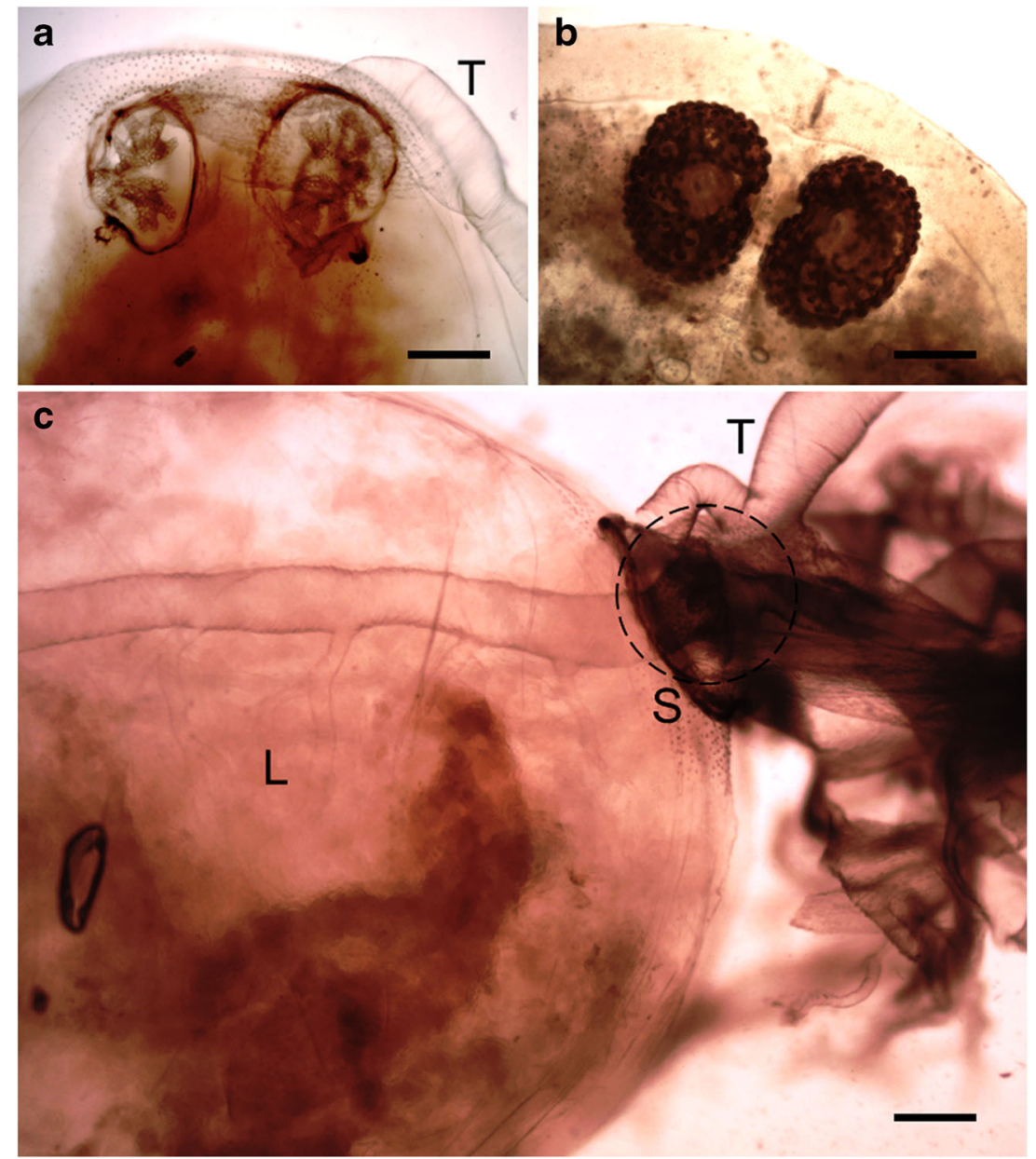

Figure 5 Larvae of Physocephala nervosa (Diptera) found in Bombus atratus and Bombus bellicosus from Uruguay during season 2012-2013. a L3 stage: posterior spiracles showing coral-like morphology. A portion of host tracheae $(T)$ still attached is indicated. b Late L3 stage: multi-pointed posterior spiracles with wart-like protuberances. c Lateral view of a L3. The dot-line circle indicates the connection between spiracles $(S)$ and tracheal host system $(T)$. [Bright field; bars $=5 \mu \mathrm{m}$ ]

pathogen of the Asian honey bee Apis cerana Fabricius, N. ceranae has been subsequently isolated from a wide range of other Apoidea species, including 18 Bombus species throughout Argentina, Uruguay, China, and United Kingdom (Ravoet et al. 2014; Plischuk and Lange 2016). It is believed that it could be of significant impact on bumble bee populations (Plischuk et al. 2009; Li et al. 2012; Graystock et al. 2013; Arbulo et al. 2015; Plischuk and Lange 2016), especially in those areas where managed bees may be a source of spores increasing the propagule pressure on wild pollinators (see Fürst et al. 2014). Our study shows prevalence values substantially lower compared to recent results published by Arbulo et al. (2015) who have reported high prevalence of $N$. ceranae in both B. atratus $(72 \%)$ and $B$. bellicosus $(63 \%)$ in other localities (albeit nearby) of Uruguay. This disparity could be due to different detection techniques used. Conversely, values are higher than those obtained in the same host species from Argentina (mean prevalence of $12.5 \%$ in B. atratus and $6.2 \%$ in B. bellicosus; Plischuk et al. 2009) and also than 
others obtained in several Bombus species from China and United Kingdom (Li et al. 2012; Graystock et al. 2013).

Tubulinosema pampeana is a recently described microsporidium discovered in Argentina. Contrary to $N$. ceranae, knowledge about T. pampeana is still limited. Prevalence in that country ranged from 1.5 to $11.9 \%$ along four sampling seasons, averaging $5.3 \%$ (Plischuk et al. 2015). Although somewhat higher, prevalence in Uruguay did not seem to be too different from that reported in Argentina albeit patchiness in its distribution seems to be more marked. We have found it in Montevideo at a high prevalence, but it was virtually undetected in samples from the other five sites. Overall, results obtained in Argentina have shown a similar trend after a geographically extensive sampling during 4 years with more than $98 \%$ of the cases restricted to the northeastern region of Buenos Aires province. Gross pathology of infections detected in Uruguay has shown the same adipose tissue alterations than those described by Plischuk et al. (2015).

Nosema bombi, a microsporidium that affects Bombus species almost worldwide and recently detected in samples of the non-native $B$. terrestris from southern Chile (Schmid-Hempel et al. 2014), was not found during our survey in Uruguay nor in previous studies in that country (Arbulo et al. 2015) and in Argentina (Plischuk et al. 2009, 2015). The protists Crithidia bombi (Euglenozoa: Kinetoplastea) and Apicystis bombi (Apicomplexa: Neogregarinorida) are other two pathogens often associated to Bombus spp. elsewhere (Goulson and Brown 2010; Plischuk et al. 2011). In South America, the former has been found only in southwestern Argentina since 2009 (Plischuk and Lange 2009; SchmidHempel et al. 2014), whereas the latter was detected not only in southwestern Argentina but also in Colombia (Plischuk and Lange 2009; Gamboa et al. 2015). Microscopic screening did not reveal the presence of these species in this study.

\subsection{Parasites}

The best known nematode associated with Bombus bumble bees is Sphaerularia bombi, recorded in nearly 30 species of Bombus worldwide. This parasite often causes host castration in addition to flight disruption (Poinar and van der Laan 1972; Jones and Brown 2014), and even when only queens are directly affected, it may also alter the nematode-free workers' behavior if the queen of the colony is parasitized (Kadoya and Ishii 2014). The sole detections of $S$. bombi in South America were recorded in 2009, parasitizing B. atratus from Argentina at a prevalence of $8-20 \%$ as well as an intensity of one to three females per queen (Plischuk and Lange 2012). The present survey has shown prevalence higher than $40 \%$ which could indicate a significant impact in the B. atratus local populations. The high percentage of mixed infections with microsporidia has not been reported previously elsewhere and could increase the impact upon the host. To our knowledge, the natural association of S. bombi and B. bellicosus represents a newly recorded host-parasite system. The fact that $S$. bombi was detected only in one of the six localities is likely a collecting artifact as 98 of the 99 queens in this study were sampled there.

Reports of mermithid nematodes in Hymenoptera are scarce, and observations of their occurrence parasitizing bumble bees (Apidae) are based only on short, isolated comments (e.g., Durrer and Schmid-Hempel 1995). Unfortunately, the absence of diagnostic characters in mermithid larvae and the lack of detections of adult stages or even eggs (Stock and Goodrich Blair 2012) do not allow an accurate identification.

\subsection{Parasitoids}

Relationships between parasitoid Diptera and Hymenoptera have been reported in several regions worldwide. Species belonging to the family Conopidae are the most common flies associated with bumble bees. Their presence may trigger abnormal responses in the host, such as altered foraging patterns as well as staying overnight outside the nest. A self-burial behavior was also described in the final phase of the parasitoidism (Müller and SchmidHempel 1993; Müller 1994). Members of other families such as Tachinidae, Phoridae, Sarcophagidae, and Calliphoridae have been also recovered from Bombus species elsewhere (Freeman 1966; Knutson and Murphy 1990). To our knowledge, 
reports about dipterans harbored by South American Bombus species are few, limited to those ofDe Santis (1989) and Abdalla et al. (2014) —Conopidae, Marcondes et al. (2011) — Tachinidae [although possibly Conopidae, see Abdalla et al. (2014)], and Lucía et al. (2013) — Phoridae.

In this survey, due to the absence of adult specimens as in the case of mermithids, an unequivocal, morphological specific identification was not possible (Gibson and Skevington 2013). Considering all samples together as one group, the range of prevalence in Uruguay (1-8\%) was similar to that observed during 2010 and 2011 in Argentina (1.7-7.5\%; Skevington and Plischuk, unpublished data), but considerably less than values reported by Abdalla et al. (2014) $(\approx 45 \%)$ in B. morio (Swederus) from Brazil.

Molecular techniques were used to identify three specimens. Two of them produced a high probability match for Physocephala nervosa. Bombus atratus has already been recorded as a host for this fly species in Argentina (Buenos Aires province) by De Santis (1989). We also have previous, unpublished records of P. nervosa parasitizing $B$. atratus from Buenos Aires, Formosa, and Córdoba provinces in Argentina (NCBI accession numbers KX536522, KX536523, KX536526 to KX536540). These results expand the known distribution for $P$. nervosa to include Uruguay (departments of Colonia and Florida) and other regions of Argentina, and support the notion that $P$. nervosa is a widespread South American parasitoid of $B$. atratus . One larval specimen is clearly a species of Physocephala but does not match any sequenced adults. Our barcode database for conopids is still incomplete so it is not surprising that one larva cannot be matched with any sequenced species. Multiple species of conopids are known to attack single host species (Stuke et al. 2011), so the finding of two species in a single host is not unexpected.

\section{CONCLUSION}

The structure of the natural enemy complex of $B$. atratus and B. bellicosus, albeit different, has presented some similar trends. First, $N$. ceranae has been detected mainly as single infections (less than $6 \%$ of co-infections) in both hosts. Knowledge about effects of this microsporidium on bumble bee individuals has grown considerably in recent years (Graystock et al. 2013). Unfortunately, to our knowledge, studies on the impact of this microsporidium at the colony level are not yet available. The high prevalence observed in Uruguayan Bombus suggests not only a conceivable enhanced impact on B. atratus / B. bellicosus populations but also a possible bidirectional flow of infective spores between bumble bees and honey bees with the consequent, simultaneous damage to the local beekeeping industry (Fürst et al. 2014; Goulson and Hughes 2015).

On the contrary, the consequences of $T$. pampeana infections still remain enigmatic. This species has been found in B. atratus only, and it has shown higher prevalence in queens whereas it was not detected in males. Mixed infections with the nematode $S$. bombi were relatively common. Since it is believed that $S$. bombi parasitizes overwintering queens and the spore loads of T. pampeana were very heavy, microsporidian infections must have already been present while queens were still young. This suggests that T. pampeana would not be too detrimental, keeping the queen alive throughout winter and ensuring a great load of infective forms to the next season. Tubulinosema pampeana affects the host adipose tissue; therefore, host energy reserves and foraging ability could be diminished affecting agricultural production based on bumble bee pollination, but mortality rates probably would be low. Tubulinosema pampeana has not been found infecting other pollinators, so it is still unknown if more species can act as reservoirs or hosts of this pathogen, as in the case of N. ceranae (Ravoet et al. 2014). Our findings expand the geographical distribution of T. pampeana .

Finally, deeper studies on the less prevalent Diptera and Mermithidae should be encouraged in order to (1) identify associated parasites/parasitoids at specific level and (2) reach a better understanding of these poorly known host-parasite/parasitoid complex, especially in terms of fitness decline of affected host populations.

Bombus atratus is the only South American native bumble bee that has been reared in captivity 
(Prieto and Cure 2012; Salvarrey et al. 2013) and commercialized as trade hives for pollination purposes (http://www.brometan.com.ar/NewSite/ pagina.php?parent=biocontrol\&slug=polinizacion-biologica-con-bombus-atratus). Based on novel data obtained in this study, strict sanitary monitoring is encouraged, particularly in breeding colonies. These results should be also kept in mind concerning potential introductions of non-native Bombus to the region (Sachman-Ruiz et al. 2015).

\section{ACKNOWLEDGMENTS}

Authors are grateful to L. Castelli, T. van Haaren, M. Higes, M. Wood, and two anonymous reviewers. This study was supported by Consejo Nacional de Investigaciones Científicas y Técnicas (CONICET), Agencia Nacional de Promoción Científica y Tecnológica (PICT 2012-0851; PICT 2012-0199), and Comisión Sectorial de Investigación Científica (CSICSP C704/102).

Author's contribution Sampling: SS, NA, ES; Sample analyses: SP, JHS, SK, PDR, CEL, CI; Ms writing: SP, CEL, JHS, MDM, CI.

Pathogènes, parasites et parasitoïdes associés aux bourdons (Bombus sp.) en Uruguay

Conopidae / Microsporidae / Nematoda / pollinisateur

Pathogene, Parasiten und Parasitoide in Verbindung mit Hummeln (Bombus spp.) aus Uruguay.

\section{Conopidae / Microsporidien / Nematoden / Bestäuber}

\section{REFERENCES}

Abdalla, F. C., Sampaio, G., Pedrosa, M., Sipriano, T. P., Domingues, C. E. C., Silva-Zacarin, E. C. M., Camargo, D. A. (2014) Larval development of Physocephala (Diptera, Conopidae) in the bumble bee Bombus morio (Hymenoptera, Apidae). Rev. Bras. Entomol. 58 (4), 343-348

Arbulo, N., Antúnez, K., Salvarrey, S., Santos, E., Branchiccela, B., Martín-Hernández, R., Higes, M., Invernizzi, C. (2015) High prevalence and infection levels of Nosema ceranae in bumblebees Bombus atratus and Bombus bellicosus from Uruguay. J. Invertebr. Pathol. 130, 165-168
Arbulo, N., Santos, E., Salvarrey, S., Invernizzi, C. (2011) Proboscis length and resource utilization in two Uruguayan bumblebees: Bombus atratus Franklin and Bombus bellicosus Smith (Hymenoptera: Apidae). Neotrop. Entomol. 40 (1), 72-77

Cameron, S. A., Hines, H. M., Williams, P. H. (2007) A comprehensive phylogeny of the bumble bees (Bombus ). Biol. J. Linn. Soc. 91, 161-188

De Santis, L. (1989) Parasitoide e hiperparasitoide de un insecto polinizador de Argentina, Bolivia, Paraguay, Uruguay y sur de Brasil. Acad. Nac. Agron. Vet. 53 (2), 5-8

Durrer, S., Schmid-Hempel, P. (1995) Parasites and the regional distribution of bumblebee species. Ecography $18,114-122$

Folmer, O., Black, M., Hoeh, W., Lutz, R., Vrijenhoek, R. (1994) DNA primers for amplification of mitochondrial cytochrome c oxidase subunit I from diverse metazoan invertebrates. Mol. Mar. Biol. Biotech. 3, 294-299

Freeman, B. A. (1966) Notes on Conopid flies, including insect host, plant and phoretic relationships (Diptera: Conopidae). J. Kansas Entomol. Soc. 39 (1), 123-131

Fürst, M. A., McMahon, D. P., Osborne, J. L., Paxton, R. J., Brown, M. J. F. (2014) Disease associations between honeybees and bumblebees as a threat to wild pollinators. Nature 506 (7488), 364-366

Gamboa, V., Ravoet, J., Brunain, M., Smagghe, G., Meeus, I., Figueroa, J., Riaño, D., de Graaf, D. C. (2015) Bee pathogens found in Bombus atratus from Colombia: a case study. J. Invertebr. Pathol. 129, 36-39

Gibson, J. F., Skevington, J. H. (2013) Phylogeny and taxonomic revision of all genera of Conopidae (Diptera) based on morphological data. Zool. J. Linn. Soc. $167,43-81$

Gibson, J. F., Kelso, S., Jackson, M., Kits, J., Miranda, G. F. G., Skevington, J. H. (2011) Novel, Dipteraspecific PCR-amplification primers of use in molecular phylogenetic research. Ann. Entomol. Soc. Am. 104, 976-997

Goulson, D., Brown, M. J. F. (2010) Natural enemies, in: Goulson, D. (Ed.), Bumblebees: behaviour, ecology, and conservation, 2nd ed. Oxford University Press Inc., New York, pp. 57-80

Goulson, D., Hughes, W. O. H. (2015) Mitigating the anthropogenic spread of bee parasites to protect wild pollinators. Biol. Conservat. 191, 10-19

Graystock, P., Yates, K., Darvill, B., Goulson, D., Hughes, W. O. H. (2013) Emerging dangers: deadly effects of an emergent parasite in a new pollinator host. J. Invertebr. Pathol. 114, 114-119

Jones, C. M., Brown, M. J. F. (2014) Parasites and genetic diversity in an invasive bumblebee. J. Anim. Ecol. 83, $1428-1440$

Kadoya, E. Z., Ishii, H. S. (2014) Host manipulation of bumble bee queens by Sphaerularia nematodes indirectly affects foraging of non-host workers. Ecology $96(5), 1361-1370$ 
Kissinger, C. N., Cameron, S. A., Thorp, R. W., White, B., Solter, L. F. (2011) Survey of bumble bee (Bombus) pathogens and parasites in Illinois and selected areas of northern California and southern Oregon. J. Invertebr. Pathol. 107 (3), 220-224

Knutson, L., Murphy, W. L. (1990) Diptera (flies) as pests of honeybees, in: Morse, R. A. (Ed.), Honey bee pests, predators and diseases. Cornell Univ. Press, New York, pp. 121-134

Lange, C. E. (1996) Protistas patógenos de insectos terrestres, in: Lecuona, R. (Ed.), Microorganismos patógenos empleados en el control microbiano de plagas. Mariano Mas, Buenos Aires, pp. 87-104

Lange, C. E., Lord, J. C. (2012) Protistan entomopathogens, in: Vega, F., Kaya, H. (Eds.), Insect pathology and microbial control. Academic Press, San Diego, pp. 367-394

Li, J., Chen, W., Wu, J., Peng, W., An, J., Schmid-Hempel, P., Schmid-Hempel, R. (2012) Diversity of Nosema associated with bumblebees (Bombus spp.) from China. Int. J. Parasitol. 42, 49-61

Lucía, M., Alvarez, L. J., Abrahamovich, A. H. (2013) First record of Melaloncha (Diptera: Phoridae) parasitoid associated with Bombus (Apidae: Bombini) in Argentina. J. Apic. Res. 52 (2), 72-73

Marcondes, M., Pinheiro, F. A. C. G., Morbiolo, S. R., Camargo, D. A., Cláudio, V. C., Sampaio, G., Abdalla, F. C. (2011) Flying with the enemy: an endoparasitic fly larva in Brazilian bumblebees. Internat. J. Biodiv. Conserv. 3 (8), 383-385

Moure, J. S., Melo, G. A. R. (2012) Bombini Latreille, 1802, in: Moure, J.S., Urban, D., Melo, G. A. R. (Eds.), Catalogue of Bees (Hymenoptera, Apoidea) in the Neotropical Region [online] http://www.moure.cria.org.br/ catalogue (accessed on 05 Apr 16)

Müller, C. B. (1994) Parasitoid induced digging behaviour in bumblebee workers. Anim. Behav. 48 (4), 961-966

Müller, C. B., Schmid-Hempel, P. (1993) Exploitation of cold temperature as defence against parasitoids in bumblebees. Nature 363, 65-66

Onstad, D. W., Fuxa, J. R., Humber, R. A., Oestergaard, J., Shapiro-Ilan, D. I., Gouli, V. V., Anderson, R. S., Andreadis, T. G., Lacey, L. A. (2006) An Abridged Glossary of Terms Used in Invertebrate Pathology, 3rd Ed. Society for Invertebrate Pathology [on line] http:// www.sipweb.org/resources/glossary (accessed on 04 Jul 2016)

Plischuk, S., Lange, C. E. (2009) Invasive Bombus terrestris (Hymenoptera: Apidae) parasitized by a flagellate (Euglenozoa: Kinetoplastea) and a neogregarine (Apicomplexa: Neogregarinorida). J. Invertebr. Pathol. 102, 263-265

Plischuk, S., Lange, C. E. (2012) Sphaerularia bombi (Nematoda: Sphaerulariidae) parasitizing Bombus atratus (Hymenoptera: Apidae) in southern South America. Parasitol. Res. 111, 947-950

Plischuk, S., Lange, C. E. (2016) Bombus brasiliensis Lepeletier (Hymenoptera, Apidae) infected with Nosema ceranae (Microsporidia). Rev. Bras. Entomol., DOI: 10.1016/j.rbe.2016.06.003
Plischuk, S., Martín-Hernández, R., Prieto, L., Lucía, M., Botías, C., Meana, A., Abrahamovich, A. H., Lange, C. E., Higes, M. (2009). South American native bumblebees (Hymenoptera: Apidae) infected by Nosema ceranae (Microsporidia), an emerging pathogen of honeybees (Apis mellifera). Environ. Microbiol. Rep. 1, 131-135

Plischuk, S., Meeus, I., Smagghe, G., Lange, C. E. (2011) Apicystis bombi (Apicomplexa: Neogregarinorida) parasitizing Apis mellifera and Bombus terrestris (Hymenoptera: Apidae) in Argentina. Environ. Microbiol. Rep. 3, 565-568

Plischuk, S., Sanscrainte, N. D., Becnel, J. J., Estep, A. S., Lange, C. E. (2015) Tubulinosema pampeana sp. n. (Microsporidia, Tubulinosematidae), a pathogen of the South American bumble bee Bombus atratus. J. Invertebr. Pathol. 126, 31-42

Poinar Jr., G. O. (1977) CIH key to the groups and genera of nematode parasites of invertebrates. Commonwealth Agricultural Bureaux, Bucks

Poinar Jr., G. O., Thomas, G. M. (1984) Laboratory guide to insect pathogens and parasites. Plenum Press, New York

Poinar, G. O. Jr, van der Laan, P. A. (1972) Morphology and life history of Sphaerularia bombi. Nematologica 18, 239-252

Pouvreau, A. (1962) Contribution à l'étude de Sphaerularia bombi (Nematoda, Tylenchida), parasite des reines de bourdons. Ann. Abeille 5, 181-199

Prieto, D. L. R., Cure, J. R. (2012) Desarrollo de colonias de Bombus atratus (Hymenoptera: Apidae) en cautiverio durante la etapa subsocial. Revista Fac. Ciencias B. 8 (1), 28-33

Ravoet, J., De Smet, L., Meeus, I., Smagghe, G., Wenseleers, T., de Graaf, C. D. (2014) Widespread occurrence of honey bee pathogens in solitary bees. J. Invertebr. Pathol. 122, 55-58

Rutrecht, S. T., Brown, M. J. F. (2008) The life-history impact and implications of multiple parasites for bumble bee queens. Int. J. Parasitol. 38 (7), 799-808

Sachman-Ruiz, B., Narváez-Padilla, V., Reynaud, E. (2015) Commercial Bombus impatiens as reservoirs of emerging infectious diseases in central México. Biol. Invasions 17 (7), 2043-2053

Salvarrey, S., Arbulo, N., Santos, E., Invernizzi, C. (2013) Cría artificial de abejorros nativos Bombus atratus y Bombus bellicosus (Hymenoptera, Apidae). Agrociencia Uruguay 17 (2), 75-82

Santos, E., Arbulo, N., Salvarrey, S., Invernizzi, C. (2013) First study of distribution of species of the genus Bombus (Hymenoptera, Apidae) in Uruguay. Proceed. 43rd Apimondia Cong. Kyiv, Ukranie

Schmid-Hempel, R., Schmid-Hempel, P. (1996) Larval development of two parasitic flies (Conopidae) in the common host Bombus pascuorum . Ecol. Entomol. 21 (1), 63-70

Schmid-Hempel, R., Eckhart, M., Goulson, D., Heinzmann, D., Lange, C., et al. (2014) The invasion of southern South America by imported bumblebees and associated parasites. J. Anim. Ecol. 83 (4), 823-837 
Siddiqi, M. R. (2000) Tylenchida: parasites of plants and insects. CABI, Oxon

Solter, L. F., Becnel, J. J., Oi, D. H. (2012) Microsporidian entomopathogens, in: Vega, F., Kaya, H. (Eds.), Insect pathology and microbial control. Academic Press, San Diego, pp. 221-264

Stock, S. P., Goodrich Blair, H. (2012) Nematode parasites, pathogens and associates of insects and invertebrates of economic importance, in: Lacey, L. A. (Ed.),
Manual of techniques in invertebrate pathology, Second Edition. Academic Press, London, pp. 373-425

Stuke, J. H., Lucía, M., Abrahamovich, A. H. (2011) Host records of Physocephala wulpi Camras, with a description of the puparium (Diptera: Conopidae). Zootaxa 3038, 61-67

Undeen, H. H., Vávra, J. (1997) Research methods for entomopathogenic protozoa, in: Lacey, L. (Ed.), Manual of techniques in insect pathology. Academic Press, New York, pp. 117-151 